\title{
Scales and scenarios of change in the anthropology-landscape relationship: models of cultural tourism in Fuerteventura (Canary Isles)
}

\author{
D. Ruiz-Labourdette ${ }^{1}$, P. Díaz ${ }^{1}$, A. J. Rodríguez ${ }^{2}$, A. Santana ${ }^{2}$, \\ M. F. Schmitz ${ }^{1}$ \& F. D. Pineda ${ }^{1}$ \\ ${ }^{1}$ Complutense University of Madrid, Spain \\ ${ }^{2}$ La Laguna University, Spain
}

\begin{abstract}
Tourism is a crucial part of the economy of the Canary Isles (Spain) and its potential with regard to its 'ecological' and 'cultural' facets has not yet been well addressed. These perspectives could lead the industry towards a model of sustainability that is as yet lacking in Spain's usual tourism: the way in which this industry has been managed has been successful in the financial sense, but erroneous in relation to socio-economy and sustainability. In the Canary Isles, the tourism continues to have a serious environmental cost. In this archipelago, a National Park has been planned for the near future on Fuerteventura. This reference enables the creation of scenarios based on new perspectives. We have developed a model of the interdependence between the island's anthropological structure and that of its natural and cultural landscape. The model is based upon multiple regression. The procedure is tested at different spatial scales. The results establish $i$ ) the parameters with which this interdependence becomes more or less strong, ii) the way in which the degree of interdependence varies in counties of different sizes, and iii) the interest of these parameters to be used as indicators of change, considering scenarios deriving from the new perspectives.
\end{abstract}

Keywords: protected area, socioeconomy-landscape relationship, tourism.

\section{Introduction}

A National Park has been planned for the Canary island Fuerteventura. This category of protection of nature would guarantee the maintenance of the natural 
resources of a territory that to date has not been given sufficient protection, despite its naturalistic, aesthetic and cultural uniqueness. At the same time it constitutes a reference to lead the way for cultural tourism and nature. The declaration of natural spaces, however, quite often involves the disadvantage that the natural values to be protected refer exclusively to the wild character of the territory, as vegetation, fauna or landscape, without sufficiently considering the local population, its culture, lifestyle or cultural landscape deriving therefrom (Sayer [1]). These features have rarely been included among the objectives of 'nature' conservation. Neither has sufficient attention been paid to the participation of this population in decisions relating to the boundaries, and area, of the protected space or to the type of future management of the natural resources (Bruner et al. [2], Sayer and Campbell [3], Ruíz-Pérez et al. [4]).

At present, Fuerteventura, to some extent is still an 'empty' island, compared to other tourist areas on the archipelago but, as has occurred with other islands, it is in danger of being taken over by big hotels and apartment complexes and of losing much of its natural landscape. To attenuate this, and to better conserve natural and cultural values, the 'man and biosphere' program (MaB, Unesco) has also recently declared Fuerteventura as a Biosphere Reserve. The environmental values to be found on this island are as important as anywhere else on the Canaries, where economic development has focussed particularly upon mass tourism, ignoring the island's natural areas and rural cultural landscape. In Fuerteventura, however, there is still relatively little tourism, and this reserve could in fact constitute a good reference for an alternative and more sustainable form of tourism, based on landscape, nature and culture. The very definition of these reserves includes the local population and the cultural landscapes traditionally associated with these. National Park status in Spain involves strict legal protection of the natural values therein, which has been lacking to date in the Biosphere Reserves (Lope de Toledo [5]). A National Park can also constitute the maximum-protection, 'nucleus sector', of the Reserve, around which the future development model of the whole island would be designed.

In this chapter we analyse the 'landscape-socioeconomy' interdependence relationship in Fuerteventura, as we believe that this knowledge should be the basis of any demarcation of the island's best-known natural values, which justify its declaration as a National Park. The analysis was performed through the application of a multivariate model of ordination and multiple regression formalising this relationship. The procedure was tested in previous studies (Schmitz et al. [6], De Aranzabal et al. [7]), and different spatial scales have now been updated and incorporated into the analysis in order to express the relationship. The results can be used as a reference for a scenario of socioeconomic change which perhaps is not very drastic, but which has likely been promoted to a certain degree by the new National Park status.

\section{Materials and methods}

Fuerteventura is one of the Canary Isles' largest islands $\left(1731 \mathrm{~km}^{2}\right)$. It is a desert island $-110 \mathrm{~mm}$ of rainfall, hardly reaching $200 \mathrm{~mm}$ at the highest elevations-, 
flat, compared with other islands of the archipelago, with unique and attractive volcanic landscapes, with notably broad visual basins; most of the land is ochrecoloured, with outcrops of black basaltic rocks in many places inland and on some coastal cliffs. The colouring of the substrate and the geomorphology make the coasts in particular quite varied in all their orientations, with spectacular beaches that are highly appreciated by the tourists (Criado [8], RodríguezDelgado [9], Paredes and Rodríguez [10], Pineda [11]). Extensive goat herding and artisanal fishing close to the coast ('pesca de bajura') have historically characterised the relevant rural activities. Agriculture has been concentrated in some valley bottoms, with legumes and vegetables (almost exclusively potatoes, onions, chick peas and lentils), and some flat areas and slope zones with characteristic terraces ('gavias'), where some varieties of early cereals have been successfully grown. Agriculture on this island has been historically considered as very important, with products being exported to other islands, but one can now observe evident soil exhaustion and rural abandonment. In the last decade, this has run parallel to the development of mass 'sun and sand' tourism. Livestock farming is prospering, especially with the stabling of goats for the production of the excellent 'majorero' cheese, which is in great demand -Santana Talavera [12], Burriel [13], García and Zapata [14] (the goat is a popular symbol in Fuerteventura)-. The island is administratively organised into six town councils, within whose municipalities we have considered a total of 51 population nuclei for our study. Although these are dispersed throughout the territory, the island still presents a relatively 'empty' character.

\subsection{Characterisation and zoning of the landscape}

We delimited the spatial units of landscape, adopting for this concept (Pineda et al. [15], Bernáldez [16]) a Cartesian view (Forman [17], Forman and Godron [18]). The units were (Fig. 1): 1. Warm/dry plains. Steppic vegetation, 'gavias' and abandoned croplands. 2. Warm/dry slopes and valley bottoms. Different types of shrubland, 'gavias' on slopes and gardening. 3. Sandy terrain, dunes, coastal dunes on warm/dry flat terrain. Psamophyllous vegetation. 4. Active aeolic sandy deposits and carbonate crusts ('caliche'), steppic vegetation and croplands. 5. Piedmonts and ravines with scrubland and abandoned 'gavias' in warm zones. 6. Warm/wet mountaintops and slopes. Summer rainfall. Scrubland ('jorados', 'cardonales', sweet 'tabaibales'). 7. Warm/wet mountaintops and slopes. 'Tabaibales' and 'cardales' of wild artichoke. 8. Warm/wet mountaintops and slopes. Scrubland of 'algoaera' and 'mato'. Abandoned 'gavias'. To obtain these units, we used information from Pineda [11], Del Arco [19], Wildprett and Martin-Osorio [20], Tejedor et al. [21]. Thus, we present the data on the physical environment on a grid with $100 \times 100$ m cells: climate, lithology and topographysurface hydric dynamics (Table $1(a)$ ). With each of these three datasets, we designed different matrices whose observations were the cells of the grid and the variables the previously described ones. Each of the matrices was treated by means of multivariate ordination analyses. The coordinates of the cells on the first two axes calculated for each of these three datasets enabled us to use these 
axes as new physical variables ('environmental synthesis variables' or 'conditioning factors'). The axes were classified into several geotic zones by means of a random divisive procedure. Upon these zones, we placed the units from the island's vegetation and land uses map, finally obtaining the 'landscape units' map (Table 1(b) and Fig. 1).

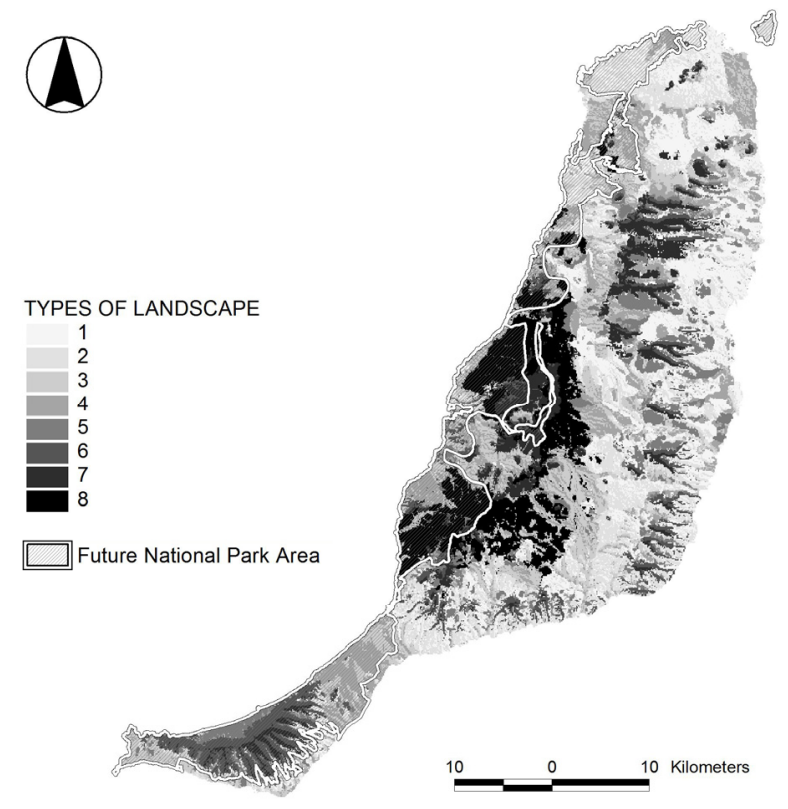

Figure 1: $\quad$ Map of the types of landscape differentiated on Fuerteventura.

Table 1: List of physical and biological (geobotanical) characteristics and of land used to design the data matrix for the creation of landscape units.

\begin{tabular}{|c|}
\hline (a) Physical characteristics \\
\hline Climatic \\
\hline $\begin{array}{c}\text { Rainfall (in each season and annual), temperature (average of summer } \\
\text { maximums, inverse of the average of winter minimums, continentality } \\
\text { index, annual radiation). }\end{array}$ \\
\hline Lithologic \\
\hline 47 lithologic classes. \\
Topographic \\
\hline Altitude, slope, roughness, orientation, hydric convergence-divergence. \\
\hline (b) Geobotanic characteristics and land uses \\
\hline 31 geobotanic classes and 49 types of land use. \\
\hline
\end{tabular}




\subsection{Socioeconomic structure}

The 51 population nuclei differentiated were taken as observations of a new data matrix with 114 socioeconomic variables (Table 2). We used the matrix to characterise the socioeconomic structure of the island, synthesising it into the variation tendencies shown by the first two axes of a multivariate ordination analysis of this matrix. The reference to these 51 entities was obliged by the assignation thereto of socioeconomic data available in the statistical tables of the Canary Isles and Spanish Administrations.

Table 2: Types of socioeconomic features recorded by the Canary Isles Administration and assigned to the population nuclei of Fuerteventura.

\begin{tabular}{|c|}
\hline $\begin{array}{l}\text { 1. Number of goods of cultural interest }-1 \text { variable (museums, monuments, } \\
\text { archaeological localities, etc.)-. }\end{array}$ \\
\hline 2. Type of housing -15 variables (housing and storey buildings)-. \\
\hline 3. Type of houses -10 variables (net usable area)-. \\
\hline 4. Year of house construction -9 variables (before 1900/after 2001)-. \\
\hline $\begin{array}{l}\text { 5. Condition of the building }-4 \text { variables (dilapidated, bad, deficient and good } \\
\text { condition)-. }\end{array}$ \\
\hline $\begin{array}{c}\text { 6. House services }-23 \text { variables (communications, green spaces, cleanliness, } \\
\text { delinquency, noise, smell, running water, sewer and drainage system, toilet, cooling } \\
\text { and telephone installation)-. }\end{array}$ \\
\hline 7. Number of vehicles. \\
\hline 8. Number of persons living in a household -8 variables ( 1 person/ more than 8$)-$. \\
\hline 9. Number of families living in a household -2 variables ( 1 family and 2 or more)-. \\
\hline $\begin{array}{l}\text { 10. Number of generations living in a household }-3 \text { variables }(1,2 \text { and } 3 \text { or more } \\
\text { generations)-. }\end{array}$ \\
\hline 11. Maximum age in the house -5 variables (From 0 to more than 80 )-. \\
\hline 12. Type of property owner -3 variables (personal, community and of a company)-. \\
\hline $\begin{array}{l}\text { 13. Number of residents with a second housing }-3 \text { variables (2nd residence in an other } \\
\text { canary island, in Spain and abroad)-. }\end{array}$ \\
\hline 14. Activity -14 variables (agriculture, fishing, construction, trading, catering, etc.)-. \\
\hline 15. Population per age class -5 variables (from 0 to 19 , to more than 80 )-. \\
\hline $\begin{array}{l}\text { 16. Place of birth }-4 \text { variables (Fuerteventura, other canary island, rest of Spain and } \\
\text { abroad)-. }\end{array}$ \\
\hline 17. Population -1 variable (total population)-. \\
\hline
\end{tabular}

\subsection{Socioeconomy-landscape relationship and scales of dependence}

The two variation tendencies of the socioeconomic structure were considered to be dependent on landscape, described by means of the set of physical, geobotanic and cultural variables mentioned in section 2.1. To formalise this dependence, 
we took separately the coordinates of the population nuclei on each of the previous axes and each was used as a dependent variable of different regression equations calculated with the landscape data (section 2.1). These data were considered as the independent variables of the equations. The data had to be assigned to the area surrounding each population nucleus. To this end, we took as observations the cells containing the 51 nuclei.

We calculated the regressions at successively smaller scales of detail (progressively bigger areas), grouping those neighboring cells that coincided with each nucleus in progressively larger areas. To this end, we grouped the cells by means of a buffer procedure that adds strips of land $0.5,1,1.5,2,3$ and $6 \mathrm{~km}$ wide around each population nucleus. In each case we calculated the dependence with the socioeconomic data corresponding to the same 51 population nuclei, with which we calculated the regressions. The increasing size of the respective areas appears to indicate the variation in dependence between the population structure and the environmental variables that best explain it at each scale.

\section{Results}

The tendencies of variation in the socioeconomic structure are shown in Table 3. The biggest socioeconomic differences found in Fuerteventura are due to variation in the size of the island's populations and the services available therein. These differences affect the inhabitants of the population nuclei presenting an aged society -with small houses, little access to services and inhabitants working in extractive industries (lower part of the first axis calculated) - compared with that of population nuclei where most people live, better access to services and based on trade, construction and real estate (upper part).

Another way of differentiating Fuertetentura's population corresponds to the rhythm of development of the population nuclei (second axis). This development is characteristic of the growth of tourism on the island. A rapid growth is associated with nuclei characterised by modern housing as rent, hotels (satellite cities), a low concentration of people per home and a non-native resident population; here, people are characteristically employed in restaurants and hotels and other tourism related industries (positive part of this axis; Table 3). The other extreme deals with moderate growth (a low concentration of people per home, traditional buildings belonging to their owners, an aging population, inhabitants working in agriculture and fishing, three or more generations per household, administrative centres with goods of cultural interest). These results tally with the typology of tourism development (Peck and Lepie [22]) as a model of 'rapid growth'. The relationship found between this variability and the landscape characteristics at scales of different details (landscape characterising the space around the entities in progressively broader strips), is shown in Table 4.

\section{Discussion}

Fuerteventura's population nuclei are arranged from a type of society with a low level of services, associated or not with the rural environment, to another with a 
Table 3: Loadings of the socioeconomic variables (first two axes of the ordination analysis performed with the set of 51 population nuclei). 114 variables were considered; the table shows those presenting higher positive or negative loading. F1: 71\% abs. variance; F2: 8\%.

\begin{tabular}{|c|c|c|c|}
\hline Variable & $\mathrm{F} 1$ & Variable & $\mathrm{F} 2$ \\
\hline Assets of Cultural Interest & 0.32 & Ages $>80$ yrs old & -0.63 \\
\hline Houses without running water & 0.38 & Ages $60-80$ yrs old & -0.57 \\
\hline 8 storey-houses & 0.46 & People born in Fuerteventura & -0.55 \\
\hline Houses dated 1900-1920 & 0.49 & Houses dated $\leq 1900$ & -0.51 \\
\hline Houses dated $\leq 1900$ & 0.52 & Households $>3$ generations & -0.49 \\
\hline Houses without sewer system & 0.53 & Assets of Cultural Interest & -0.44 \\
\hline Houses with private water & 0.57 & 2 housing per building & -0.41 \\
\hline Occupation in extractive industries & 0.58 & Houses $120-150 \mathrm{~m}^{2}$ & -0.37 \\
\hline--- & & --- & \\
\hline Houses without noise & 0.96 & People born abroad & 0.38 \\
\hline Household with one vehicle & 0.96 & Canary residents with 2 nd & 0.42 \\
\hline Household with one family & 0.97 & 4-7 storey-houses & 0.45 \\
\hline Houses without smell & 0.97 & Houses $30-45 \mathrm{~m}^{2}$ & 0.45 \\
\hline Houses $76-90 \mathrm{~m}^{2}$ & 0.97 & Houses property of a company & 0.47 \\
\hline Ages $40-50$ years old & 0.98 & More than 10 housing per & 0.52 \\
\hline Houses with toilets & 0.98 & More than 8 storey-houses & 0.54 \\
\hline Principal familiar housings & 0.99 & Houses $\leq 30 \mathrm{~m}^{2}$ & 0.63 \\
\hline Total population & 0.99 & Hotels & 0.64 \\
\hline
\end{tabular}

high level, which tends to be located in the nuclei with bigger populations. The first ordination axis shows this as a continuous variation, without polarity and an extremely high absorption of variance (Table 3 ). The opposition between the traditional rural society and one characterised by the development of tourism is shown on the second axis, presenting a clear polarity and a low level of absorbed variance, indicating a model of rapid growth. This corresponds to the current type of tourism on Fuerteventura which generates, at least, curious situations.

Thus, promoters, workers and owners are exogenous and the financial profits do not go to the local population. This situation, however, affects the local culture and the territory -Peck and Lepie [22] (according to these authors, 'slow growth' provides greater local control of development and integration of the external agents into the traditional social structures)-. The regression coefficients calculated highlight the relative importance of the different environmental factors conditioning this socioeconomic variability. Of the large set of variables used to describe the landscape, 15 explain this structure (Table 4). The variation exhibited by the first axis is the one that shows the highest and most positive regression coefficients, associated with quarrying and mining landscapes, 
58 Island Sustainability

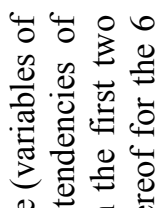

渮.

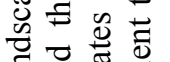

흐 몰

行

舟品过

플

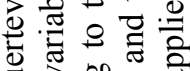

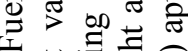

on

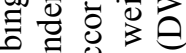

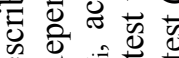

过

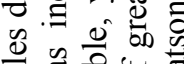

व व

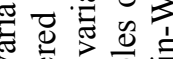

4 는

跣

ठ

\% 웧ㅇ

율

बi

递焉害

ర됼

宩

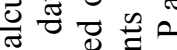

0 过.

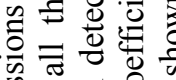

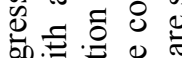

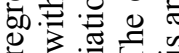

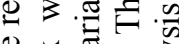

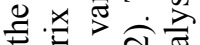

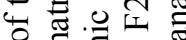

范

政

으요도

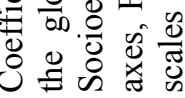

$\ddot{y}$
$\frac{0}{\frac{\pi}{\sigma}}$

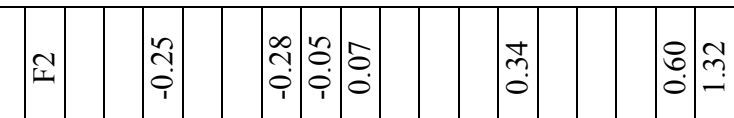

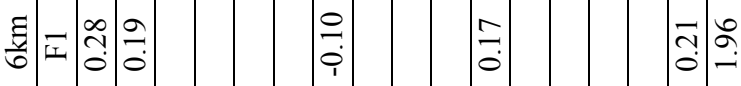

N

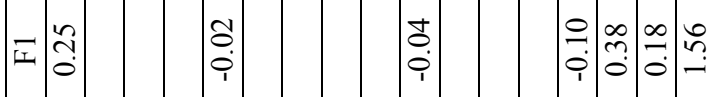

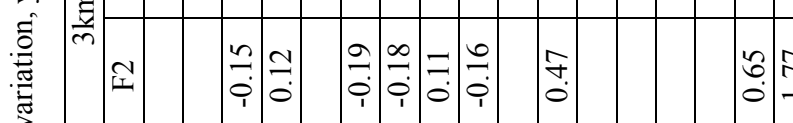

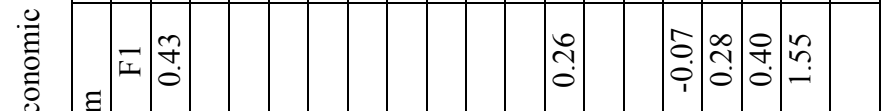

部

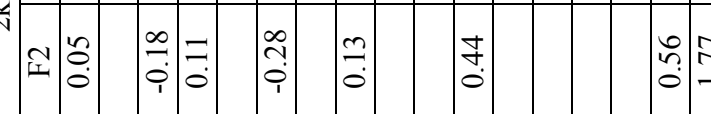

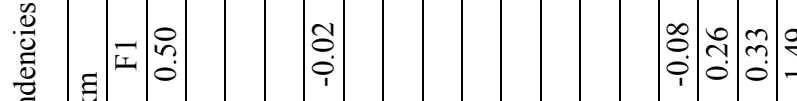
:

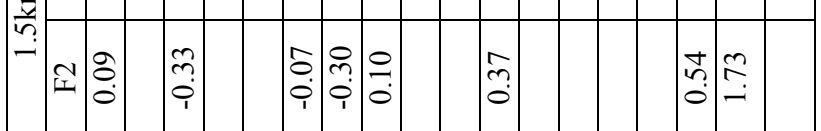

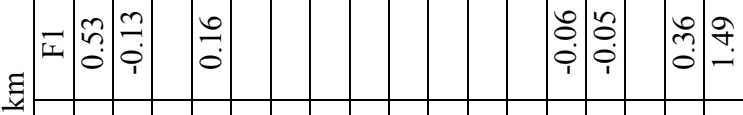

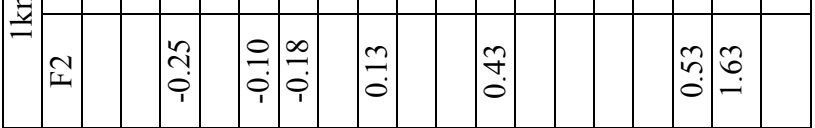

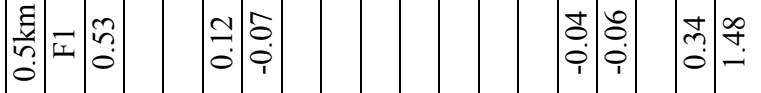

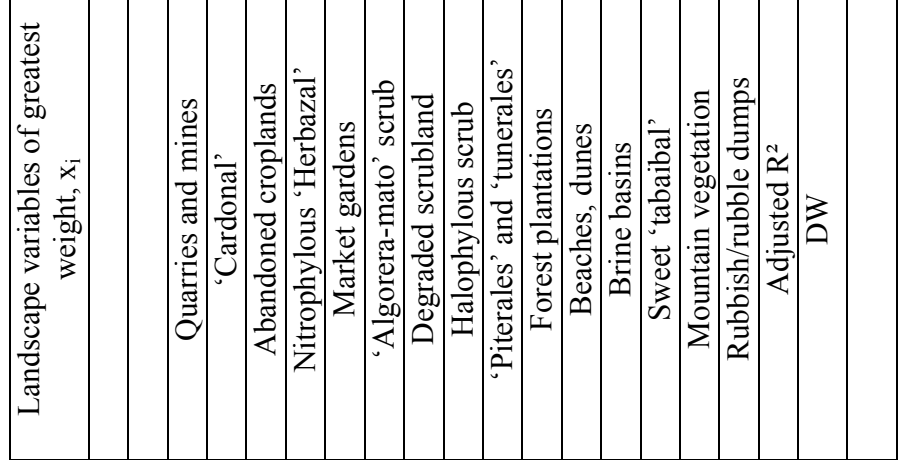

WIT Transactions on Ecology and the Environment, Vol 130, (C) 2010 WIT Press www.witpress.com, ISSN 1743-3541 (on-line) 
rubbish and rubble dumps and abandoned agricultural spaces (nitrophylous 'herbazales').

The opposite of this (places in which less people live) is the cultural rural landscape of market gardens and the natural landscape of the few mountains in the island (Table 4, F1). Abandoned croplands, landscapes with degraded vegetation and scrublands of 'algorera and mato' is what remains in landscapes typical of rural nuclei presenting a slow growth rate, whereas coastal zones with beaches and halophylous vegetation characterise the populations associated with the development of tourism (Table 4, F2). The distribution of the population on the island is very clear and synthesised by a low number of landscape variables.

As the landscape-socioeconomy scale of interdependence changes, so do some regression coefficients. The degraded urban and periurban landscape presenting hardly any components of the rural environment and occupied by a more numerous population- becomes less associated with the population as the area of analysis increases. In Table 4 the coefficients of quarries and mines decrease with scale and rubbish and rubble dumps are maintained; there is an increase in abandoned agricultural areas at the whole island scale and the landscapes moves away from a model typical of mountain areas $-\mathrm{F} 1$ from 0.5 to $6 \mathrm{~km}$; moreover the values of fit $\left(\mathrm{R}^{2}\right)$ diminish with scale-. As for the development of tourism (F2), with a change of scale, no regularity is appreciated in the dependence of the population structure on landscape so that, although it is more associated with the coast, this development appears to be quite independent from the landscape.

The budding National Park presents an absence of population nuclei in the land it will encompass, in accordance with the laws on these protected spaces (Lope de Toledo [5]), but proximity to, or distance from, its boundaries can influence the degree, territorial scale and socioeconomic variables affected by the protected space. Maintenance of the natural landscape conserved within the park's boundaries is incompatible with human activities, which have modified this type of landscape on much of the island (Santana Talavera [12], Ruiz-Pérez et al. [4]). Even outside these limits, but near, it seems inappropriate to permit, for instance, a mine or mass tourism. On the contrary, promoting human activities compatible with the kind of landscape of the park can involve a change in socioeconomic structure, at least in the vicinity of the park (Sayer et al. [23], Garnett et al. [24], Wittenmeyer et al. [25]).

The uses permitted in the park involve activities directly or indirectly associated with nature conservation and careful management of natural resources (Lope de Toledo [5], Bruner et al. [2], Sayer and Campbell [3]), so that a foreseeable result of declaring the park could involve a socioeconomic change in which conservation activities take on a level of importance heretofore unknown in Fuerteventura's society (transport cooperatives for park visitors, reception centres, monitors, merchandising, rural accommodation, etc.). It is unlikely that the park will cause a drastic change in the island's current model of tourism, but it would attenuate the aging of the population in the traditional rural areas, as well as other typical effects of the current rural exodus. 
Fig. 2 shows an ordination analysis of the landscape data measured in $2 \mathrm{~km}$ spaces around Fuerteventura's population nuclei. At this scale we found the best fit in the landscape-socioeconomy dependence $\left(R^{2}\right.$, Table 4$)$. The figure reflects the socioeconomic dynamics estimated for the population of Fuerteventura for one of the change scenarios that might be promoted by the declaration of the National Park. This involves the promotion of landscape characteristics that do not involve any alteration, that is, non-intensive activities (such as quarries and mines, abandonment of croplands; Table 4, F1, F2), but rather associated with the island's best-conserved landscapes (maintenance and promotion of valuable vegetation such as 'cardonales' and mountain landscapes; Table 4, F1, F2).

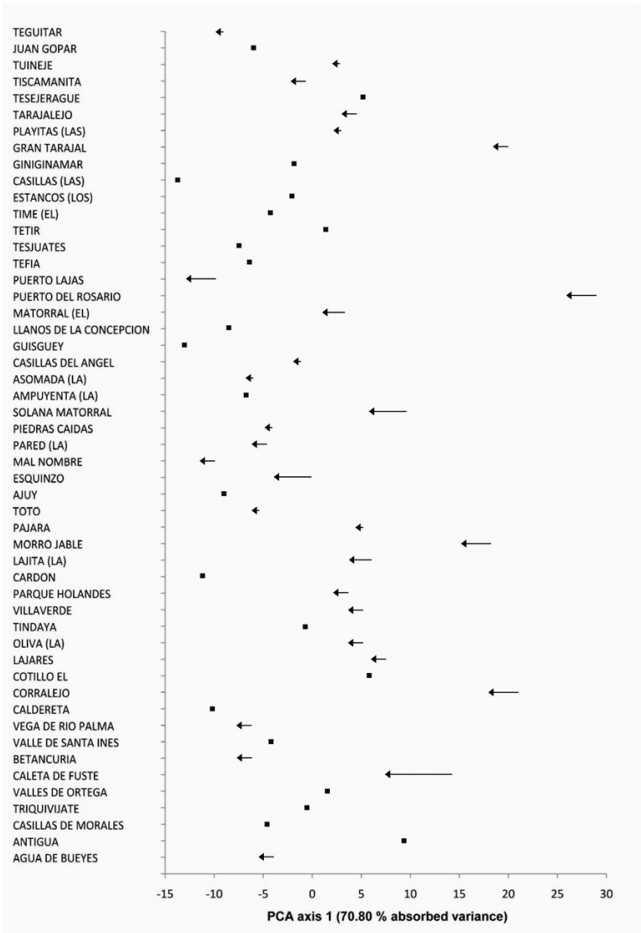

(a)

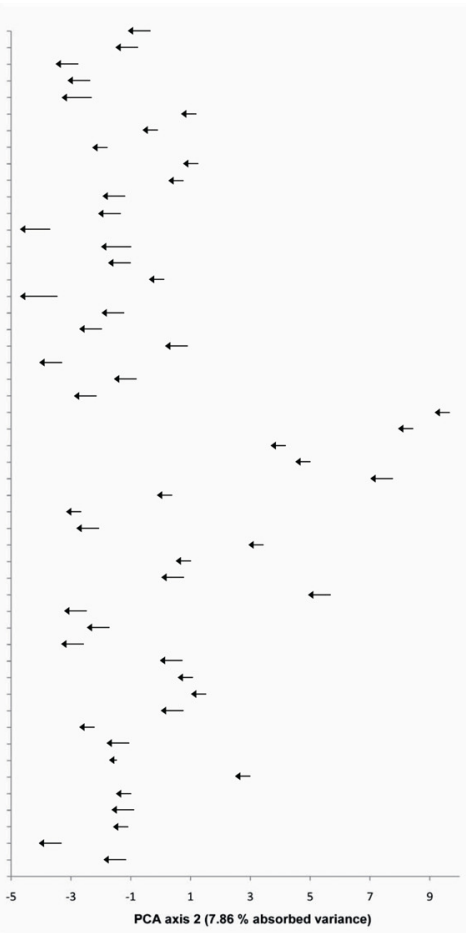

(b)

Figure 2: Ordination analysis of the socioeconomic data measured referring to Fuerteventura's population nuclei. The arrows indicate movement along the analysis axes from the original position of the nuclei to the one simulated by means of a scenario of change towards more natural landscape models. The characteristics of the original landscape and of the simulated scenario refer to spaces of 2 $\mathrm{km}$ around the population nuclei. The dots with no arrow indicate that the nucleus retains the same characteristics before and after the scenario is simulated. 
In the scenario simulated (De Aranzabal et al. [7]) there has been a $30 \%$ increase in the area of these two characteristics in a $2 \mathrm{~km}$ area around each nucleus, and a similar percentage decrease in the previous ones. A large amount of nuclei shows no change along the first axis (Fig. 2(a)), presenting a society that is quite oblivious to the change (simulated) in the characteristics of the environment. The second axis, typical of change from the traditional landscape to the 'touristic' one -characterised by hotels and similar features, Table 3-, presents noteworthy change dynamics in this scenario, which is more obvious in some nuclei than in others.

Creating the park can indeed constitute a key element for encouraging participatory actions and awareness campaigns aimed at promoting the heritage and self-esteem of the population. Appropriate management thereof can orientate local identity beyond the values induced by the current type of tourism. A revaluation of traditional uses would not only be beneficial in itself, with regard to conserving nature and culture. Provided populations feel involved, it would provide a process of economic diversification without so much financial and structural dependence on tourism. This dependence now has a vital effect on the environmental and socio-cultural aspects that influence the tourism system itself.

\section{References}

[1] Sayer, J. The People's Forest: Balancing local and global values. Doctoral Thesis (Sciences). Autónoma University, Madrid, 2007.

[2] Bruner, A.G., Gullison, R. E., Rice, R.E. and da Fonseca, G.A.B. Effectiveness of Parks in Protecting Tropical Biodiversity. Science, 291, pp. 125-128, 2001.

[3] Sayer, J.A. and B. Campbell. Research to Integrate Productivity Enhancement, Environmental Protection and Human Development. Conservation Ecology, 5(2), p. 32 [online] URL: www.consecol.org /vol5 /iss2/art32, 2001.

[4] Ruiz Pérez, M., Ezzine de Blas, D., Nasi, R. et al. Socioeconomic constraints, environmental impacts and drivers of changes in the Congo basins as perceived by logging companies. Environmental Conservation, 33(4), pp. 316-324, 2006.

[5] Lope de Toledo, J.M. Plan Director de la Red de Parques Nacionales. Organismo Autónomo Parques Nacionales, Ministerio de Medio Ambiente, Madrid [Real Decreto 1803/99, de 26 de noviembre, por el que se aprueba el Plan Director de La Red de Parques Nacionales], 1999.

[6] Schmitz, M.F., Aranzabal, I., Aguilera, P., Rescia, A. and Pineda, F.D. Relationship between landscape typology and socioeconomic structure. Scenarios of change in Spanish cultural landscapes. Ecological. Modelling, 168, pp. 343-356, 2003.

[7] De Aranzabal, I., Schmitz, M.F., Aguilera, P. and Pineda, F.D. Modelling of landscape changes derived from the dynamics of socio-ecological systems. A case of study in a semiarid Mediterranean landscape. Ecological Indicators, 8, pp. 672-685, 2008. 
[8] Criado, C. La evolución del relieve de Fuerteventura. Cabildo Insular de Fuerteventura, Puerto del Rosario, 1992.

[9] Rodríguez-Delgado, O. (coord.). Patrimonio Natural de la isla de Fuerteventura. Cabildo de Fuerteventura-Gobierno de Canarias-Centro de la Cultura Popular Canaria, Santa Cruz de Tenerife. 2005.

[10] Paredes, R. and Rodríguez, R. (coords.). Fuerteventura. RAI Ediciones, Antigua, 2002.

[11] Pineda, F.D. (dir.). Estudio para el Plan de Ordenación de los Recursos Naturales (PORN) de la propuesta de Parque Nacional de Fuerteventura en su Primera Fase. Cabildo de Fuerteventura, Universities Complutense of Madrid and La Laguna. Preliminary report, 245 pp., 2009.

[12] Santana Talavera, A. Antropología y turismo. ¿Nuevas Hordas, viejas culturas? Ariel, Barcelona, 1997.

[13] Burriel, E. Canarias: población y agricultura en una sociedad dependiente. Oikos-tau, Barcelona, 1981.

[14] García, J.L. and Zapata, V.M. Los cambios recientes en la población de Canarias. In: Geografia de Canarias. Vol. VII. Interinsular Canaria, Sta. Cruz de Tenerife, pp. 23-54, 1992.

[15] Pineda, F.D. et al. (Environmental analysis group, Ecology Dept. Sevilla University). Terrestrial eco-systems adjacent to large reservoirs. Ecological survey and impact diagnosis. Internat. Comm. on Large Dams, Icold. Madrid. Monogr. Dirección General Obras Hidráulicas, Madrid, 1974.

[16] Bernáldez, F.G. Ecología y paisaje. Blume, Madrid, 1981.

[17] Forman, R.T.T. Landscape Ecology. John Wiley, New York, 1986.

[18] Forman, R.T.T. and Godron, M. Patches and structural components for a landscape ecology. BioScience, 31, pp. 733-740, 1981.

[19] Del Arco, M. (ed.). Mapa de Vegetación de Canarias. Grafcan Eds., Santa Cruz, Tenerife, 2006.

[20] Wildprett, W. and Martin-Osorio, V.E. Vegetación y usos del suelo. In: Estudio para el Plan de Ordenación de los Recursos Naturales (Porn) de la propuesta de Parque Nacional de Fuerteventura en su Primera Fase. Cabildo de Fuerteventura, Universities Complutense of Madrid and La Laguna. Preliminary report, 245 pp, 2009.

[21] Tejedor, M., Jiménez, C., Rodríguez, A. and Neris, J. Edafología. In: Estudio para el Plan de Ordenación de los Recursos Naturales (Porn) de la propuesta de Parque Nacional de Fuerteventura en su Primera Fase. Cabildo de Fuerteventura, Universities Complutense of Madrid and La Laguna. Preliminary report, 245 pp., 2009.

[22] Peck, J.G. and Lepie, A.S. Turismo y desarrollo en tres enclaves costeros de Carolina del Norte. In: Anfitriones e invitados, ed. Smith, V.L. Endymión, Madrid, pp. 303-333, 1992.

[23] Sayer, J.A., Campbell, B. Petheram, L. et al. Assessing environmental and Development outcomes in conservation landscapes. Biodiversity and Conservation, 16(9), 2677-2694. 2006. 
[24] Garnett, S.T., Sayer, J.A. and du Toit, J. Improving the effectiveness of Interventions to Balance Conservation and Development: a Conceptual Framework. Ecology and Society, 12(1), p. 2 [online] URL: www.ecologyandsociety.org/vol12/iss1/art2, 2007.

[25] Wittemeyer, G., Elsen, P., Bean, W.T., Burton, C.O. and Brashares, J.S. Accelerated Human Population Growth at Protected Area Edges. Science, 321, pp. 123-126, 2008. 